\title{
Healthcare in emergency units: organization and ethical implications
}

\author{
Atendimento em unidade de emergência: organização e implicações éticas \\ Atención en una unidad de emergencia: organización e implicancias éticas
}

\section{Márcia Adriana Poll ${ }^{1}$, Valéria Lerch Lunardi ${ }^{2}$, Wilson Danilo Lunardi Filho ${ }^{3}$}

\begin{abstract}
This text aims to present a reflection about organizational issues, as well as possible ethical implications permeating the practice of the healthcare team at an urgency/emergency unit, providing care to victims of trauma from accidents or violence. Initially, we focused on care for external causes and its relation with work organization and ethics in the hospital environment, followed by an analysis of the ethical dimension of urgency/emergency services. The organizational and ethical issues need to be assumed by both the managers and the healthcare team working at these units since, even in precarious conditions, the professionals attempt to care for trauma victims, aiming at beneficence, even if this healthcare could cause harm when provided in inadequate conditions.
\end{abstract}

Keywords: Ethics; External causes; Emergency service, hospital/organization \& administration; Patient care team

\section{RESUMO}

Neste texto temos como objetivo apresentar uma reflexão sobre questões organizacionais, bem como possíveis implicações éticas, que permeiam a prática da equipe de saúde, numa unidade de urgência/emergência, no atendimento a vítimas de trauma decorrente de acidente e/ou violência. Inicialmente, focalizamos o atendimento às causas externas e sua relação com a organização do trabalho e a ética no ambiente hospitalar, abordando, a seguir, a dimensão ética no atendimento de urgências/emergências. As questões organizacionais e éticas necessitam ser assumidas, tanto pelos gestores quanto pela equipe de saúde que atua nestas unidades, já que, mesmo na precariedade, os profissionais tentam atender às vítimas de trauma, visando à beneficência, ainda que danos possam advir de um atendimento prestado em condições inadequadas.

Descritores: Ética; Causas externas; Serviço hospitalar de emergência/organização \& administração; Equipe de assistência ao paciente

\section{RESUMEN}

En este texto tenemos como objetivo presentar una reflexión sobre asuntos organizacionales, así como también las posibles implicancias éticas, que permean la práctica del equipo de salud, en una unidad de urgencia/emergencia, en la atención a víctimas de trauma resultante de un accidente y/o violencia. Inicialmente, enfocamos la atención a las causas externas y su relación con la organización del trabajo y la ética en el ambiente hospitalario, abordando, a seguir, la dimensión ética en la atención de urgencias/emergencias. Los temas organizacionales y éticos necesitan ser asumidos, tanto por los gestores como por el equipo de salud que trabaja en estas unidades, ya que, no obstante la precariedad, los profesionales intentan atender a las víctimas de trauma, visando la beneficencia, a pesar de los daños que puedan surgir de una atención prestada en condiciones inadecuadas.

Descriptores: Ética; Causas externas; Servicio de urgencia en hospital/organización \& administración; Grupo de atención al paciente

\footnotetext{
${ }^{1}$ Master in Nursing at Departamento de Enfermagem of Fundação Universidade de Cruz. Alta - UNICRUZ - Cruz. Alta (RS), Brazil.

${ }^{2}$ Doctor, Professor of the Nursing Master Program at Fundação Universidade de Cruz. Alta - UNICRUZ - Cruz. Alta (RS), Brazill.

${ }^{3}$ Doctor, Professor of the Nursing Master Program at Fundação Universidade de Cruz. Alta - UNICRUZ - Cruz. Alta (RS), Brazil.
} 


\section{INTRODUCTION}

Traumas are events or injuries that may or may not lead to death, caused by violence or accidents, denominated external causes*, whose high variability can mean from an elderly person's femur neck fracture to a young adult's suicide/homicide attempt: "Violence consists in individual, group, class, national human actions or their omission, which cause the death of human beings, or affect their physical, moral, mental or spiritual integrity" (1). All external causes, from "vehicular collisions to stabbing, suicides and even drownings have one thing in common: energy transfer"(2). Therefore, trauma can be defined as "a harmful event that stems from the release of specific forms of energy or physical barriers that block the normal energy flow"(2).

Such problems only reflect the tip of a huge iceberg, because the magnitude of morbidity and mortality rates remains much higher, even considering the existence of sub-registries with strong socioeconomic repercussions, not only in Brazil but also worldwide ${ }^{(4-6)}$.

The problem of external causes has been taking shape in Brazil since the 1960s, following the process of urbanization. In $1930,2 \%$ of deaths were due to accidents and violence; in 1980, 10.5\%, reaching nearly $13.5 \%$ in the late 1990 s. In these two decades, external causes were the second cause of morbidity and mortality, behind cardiovascular causes ${ }^{(1,7)}$. Between 2000 and 2004, mortality due to external causes occupied the third place ${ }^{(5,8)}$, returning to the second place in general mortality statistics in Brazil and sixth in hospital admissions in $2005^{(9)}$.

The impact of this problem can be better understood when evaluating the Years of Life Potentially Lost (YLPL), since the traumas afflict children, adolescents and young adults in a wide age range, from 5 to 49 years of age, especially from 15 to 29 years ${ }^{(1)}$. These situations, compared to the life expectation of 73.1 years reached in 2003, suggest that life expectancy could be much longer, around 73.8 years $^{(10)}$ if there were not so many deaths caused by external causes, mainly focused on the young male population ${ }^{(5,7)}$. Therefore, there is a need to search for elements that could suggest the reasons for such a receding movement over the years and reduce the impact of these losses, by looking at violence and accidents as social problems, and not only

\footnotetext{
* "Accidents and violence configure a group of health injuries that may or may not lead to death, and where so-called accidental causes - due to traffic, work, falling, poisoning, drowning and other types of accidents - and intentional causes (aggression and self-inflicted injuries). This group of events is part of the International Classification of Diseases - ICD (WHO, 1985 and WHO, 1995) - under the denomination external causes. Regarding the origin of the injury, such events cover all types of injuries and poisoning, such as wounds, fractures, burns, intoxication, drowning, among others" (3).
}

at the trauma they cause, regarding healthcare for victims in emergency units ${ }^{(1,11-12)}$.

Emergency services can be jeopardized by internal and external institutional issues that transcend actions, attitudes and desires of the healthcare workers. Therefore, as a social issue, the increased morbidity and mortality caused by external causes is reflected through ethical and organizational issues in emergency units, increasingly demanding constant updates from healthcare team professionals. If this happens, they will be able to provide healthcare for this growing demand, especially those victims afflicted by traumas caused by accidents or violence.

The complexity of the relations that are established in these places causes conflicts, dilemmas and suffering for the workers, with ethical implications in the healthcare provided to this population. Despite high numbers of violence victims, the way healthcare institutions are organized may be jeopardizing these morbidity and mortality rates even more, since they do not correspond to the healthcare needs of these users adequately. Thus, our objective was to present a reflection about organizational issues and the possible ethical implications permeating the healthcare team's practice when delivering care to victims of traumas or accidents, classified as external causes, at an urgency/ emergency unit**. For this literature review, of the narrative type, according to Rother ${ }^{(14)}$, we selected texts, among which articles, books, theses, resolutions and regulations published between 1995 and 2008, in the databases SciELO, Biblioteca Virtual em Saúde and CAPES' thesis database.

Therefore, we focused primarily on healthcare for external causes, addressing the permanently-present ethical dimension in urgency and emergency healthcare afterwards.

\section{HEALTHCARE TO VICTIMS OF EXTERNAL CAUSES: ORGANIZATION AND ETHICS}

The healthcare organization in Brazil is constituted by several healthcare modalities: according to its technological model, in public healthcare units and hospital service, due to the type of funding system, i.e. private, philanthropic, social security or state; and, also, according to the technological incorporation and healthcare levels, which can be classified as basic, secondary or tertiary healthcare. Therefore, the organization of healthcare services has not been consolidated in a homogeneous way, resulting in the existence of several forms of healthcare production ${ }^{(15)}$. In the face of this current diversity of healthcare models, it is difficult to make structures available, either hospitals or

\footnotetext{
** Urgency may be understood as "the unforeseen occurrence of a health aggravation, with or without potential risk of death, whose victim needs immediate medical assistance". Emergency is "the medical verification of aggravating health conditions implying in an imminent risk of death or intense suffering, thus demanding immediate medical treatment" (13).
} 
non-hospitals, private or public, capable and organized to receive and care for an expanding population afflicted by traumas caused by violent actions and all sorts of accidents.

\section{Organization of healthcare work}

It can still be observed that the work organization in hospital institutions is based on the classical, scientific and bureaucratic management theories, as well as culturally crystallized, dominated and conformed by the situational circumstances of the neoliberal model ${ }^{(16)}$. Hospitals inserted in this model's current context need several financial sources for their maintenance, using private healthcare plans, co-operatives and the Single Health System (SUS) as their main source of revenue. However, "even hospitals that depend largely on the SUS enjoy a reasonable degree of autonomy to organize their own work process and healthcare model"(14).

Hence, the lack of measurement standards to evaluate the quality of the healthcare provided is common, as well as the lack of efficient management of the working process, able to supervise the relations among workers, users, institutions and managers, aiming to respond to SUS directives ${ }^{(17)}$. Therefore, nowadays, in both public and private services, a distancing can be observed among managers, institutions, healthcare team and clients, causing a bureaucratic apathy, lack of interest and alienation in several healthcare services, making them paradigms of indifference and lack of sensitivity in the face of human suffering. This represents the medicalization of users without the guarantee that their problems will be solved, frequently centered on the medical appointment alone and on low-effectiveness actions ${ }^{(17-19)}$.

Thus, it can be concluded that many healthcare services are organized by "submitting the quality of work to the production, directed to a larger extent to economic interests and to a lesser extent to the promotion of man, either as a client or as a professional"(16). A grave situation becomes evident, configured as the use of a public facility for private services, since "hospitals usually offer basic, specialized and urgency services according to the primary healthcare modality"(14), i.e. immediatist and loweffectiveness healthcare. This shows a need to better qualify the management of services provided to the population, by incorporating services that are more effective and welcoming to the public apparatus. Also, professionals need to reflect on the ethics and morality when performing their work, in an attempt to break away from subalternity and submission to the organizational, system so that healthcare can be provided integrally, respecting the human being.

\section{Ethics and health}

In the healthcare area, especially in emergency units, several teams, already developing their activities, lack the necessary professional commitment in view of several emerging organizational situations, with serious ethical implications for healthcare. These need to be discussed and reflected upon. In this conception, ethics appear as a human condition of becoming ethical, and ethics itself as a factor that emerges from emotions and rationality, guided by the assumption of autonomy ${ }^{(20)}$. As such, there are basic principles that support the activities of health professionals and serve as conduct guidelines for professional ethics. These are: respect for autonomy, beneficence, non-maleficence and justice ${ }^{(21)}$.

One is considered autonomous when one has skills for self-governing, knowledge to deliberate and to make choices. As such, in the healthcare service environment, the users should be consulted about their desires, options and plans, starting with clear and accessible information about the health-disease process they are experiencing, "respecting the patient's dignity, offering a global welcome to him and his family members, and not limited to the pathology that demanded healthcare"(22). On the other hand, the healthcare professional also has the right to autonomy, even if it is not fully exercised in the work environment due to institutional rules and hierarchical standards that need to be followed.

The principle of non-maleficence has the strict task of not allowing harm and not imposing risk. The act of caring consists of acting appropriately to avoid damage, as required from prudent and sensible people ${ }^{(21)}$. In the healthcare team, bad professional practices constitute examples of maleficence caused by the inobservance of professional healthcare standards.

The principle of beneficence aims to prevent and eliminate damage, ponder and reflect on the goods that will be brought to or removed from the client, whose central goal is provide benefits and promote good ${ }^{(21)}$. This principle rules the professional activity of most teams working in emergency units, since all of them need to work based on the fact of providing good. Even though the teams may face adverse conditions to provide healthcare, they should provide it courageously sometimes even improvising, but always aiming for the quick recovery of the users.

The principle of justice deals with actions that are distributive, fair, equitable, appropriate and determined by norms, which are structurally justified in terms of social cooperation, ranging over the citizens' rights and responsibilities, in society, in civil and political terms. There is no single principle capable of solving all conflicts in this area $^{(21)}$. Therefore, a fair action considers the principles of ethics in specific cases that, when pondered in particular contexts, can be analyzed according to their real consistence. 


\section{The ethical dimension in urgency/emergency healthcare}

The healthcare system in Brazil was implanted with several administrative gaps. Therefore, it was not uniformly organized, because, not having its own, capacitated structure, it sought to outsource what was lacking with the initial purpose of providing integral healthcare coverage to the whole population. One should not forget the high costs for the public treasury, since SUS became one of the sources of revenue for private hospitals. The lack of popular indignation regarding the healthcare quality standards for users of the SUS, in turn, contributes for private institutions to keep providing them with precarious infra-structure, disrespecting constitutional rights and infringing on the ethical principles involved in each individual's health ${ }^{(14)}$.

Another factor with ethical repercussion is the deviation of users from public service to private service, generating costs for the patient who could use such a service - however, taking the public space for the provision of private healthcare. Besides, this relation entails an ethical cost, which is allied to economic interests more than to investments to promote the human being, either a healthcare user or a professional ${ }^{(16)}$.

According to this context and in the face of the appalling growth of violence and accidents, we sought to establish a relation between these factors and the emergency units, the healthcare services' entry door for the population afflicted by injuries caused by these situations $^{(11)}$. In practice, what we see is that, most of the times, these units are disorganized and ill-prepared to perform these tasks, and mainly without enough professionals who are capable and well-supported to act and receive the population afflicted by accident or violence traumas. These professionals have to face difficulties due to the bureaucratization of the service and the crystallization of organizational issues, with ethical repercussions, such as: user overcrowding, work overload, qualitative and quantitative lack of human resources, inadequate physical structure, equipment and materials that are either precarious or absent for the healthcare needed, among others.

The overcrowding problem has become more serious in the urgency/emergency service locations, a phenomenon that is known by both public and private healthcare institutions, hospitals or basic units, and also by healthcare professionals, users and the population. The consequences are high occupation rates of emergency observation beds due to the need for "fake" resolution and welcoming ${ }^{(9,17)}$, as well as constant search for medical appointments that are often unnecessary, implying costs and waste of public resources, since a good share of the population who seeks this type of service does not need it. Instead, they need low-complexity services, frequently due to non-transmissible chronic diseases that are characteristic of the population's aging process ${ }^{(23)}$.

In this reality, with a model that is still medicallycentered, the basic units themselves, when exceeding their capacity limits, or after concluding their medical records, refer the patients to emergency services, contributing to the overcrowding of these units, which, overloaded, may neglect parameters, distancing themselves from their real objective, since all the spaces are gradually taken, causing difficulties for the performance of any type of action even services directed to the most basic needs of the human beings ${ }^{(17)}$.

As such, users are frequently questioned in front of all those sharing a cramped space due to the proximity of the beds. Approaches performed by the healthcare team are witnessed by everybody present, and privacy is constantly violated ${ }^{(24-25)}$. These situations show the limitations of the environment, which submit the users to physical and moral embarrassment and hurt the principle of justice, since all users have the right to be respected in their autonomy as citizens and to receive healthcare with a physical structure, material resources and equipment that are compatible with their needs, provided by qualified personnel. The overcrowding of emergency services, "besides causing an obvious weariness due to work overload, still causes a feeling of wasting the deepest vocation of the service - that of saving lives - as well as underuse of the high technical preparation of the professionals"(17).

Therefore, the excess of activities seems to make emergency unit professionals work under constant pressure and mental overload. This condition can contribute to work accidents and mental suffering, besides several types of psychosomatic diseases, and also lead to medical prescription abuses; consumption of alcohol or other drugs, either licit or illicit; absenteeism, high turnover, professional conflicts and disciplinary administrative processes. In view of all these issues experienced, the team still needs to be prepared and qualified to minimize the aggression factors presented in many ways, at critical moments and in emotional crisis situations, in a wellbalanced mood to make all types of decisions ${ }^{(17,26-28)}$.

The team working in an emergency unit needs to be highly and professionally prepared to deliver care to users afflicted by external causes, especially because this is a sector where logic and thought happen according to the biomedical model. Therefore, continuous and permanent education, as well as training programs for the utilization of immediate trauma service protocols grant more autonomy to the healthcare team professionals, breaking paradigms and demanding conceptual transformations in care for this specific population ${ }^{(1,6,18,29)}$.

The qualification of human resources to provide care in pre-hospital, hospital and rehabilitation services, as well 
as the increasing attempts to get to know the impact of violence on health, requires new skills, equipment and organization of the healthcare system, with a well-planned physical structure, equipment, materials and fully-staffed teams, considering the characteristics of the hospital, with the goal of meeting its predetermined goal ${ }^{(9,29-30)}$. These challenges demand broad reflections, decisions and actions, which are part of public policies, including the National Policy of Accident and Violence Reduction ${ }^{(9,31)}$.

\section{FINAL CONSIDERATIONS}

Traumas due to accidents, as well as those due to violence, are an epidemiological problem with wide repercussions, not only in developing countries but globally, afflicting everybody, without distinctions of nationality or social class, exerting a huge influence in the healthcare area. In view of the impact of accidents and violence and the pressure they exert on healthcare, professionals in this area need to become aware of the gravity of the problem, because this condition is difficult to treat and also very costly. Therefore, there is a need for

\section{REFERENCES}

1. Minayo MCS. Violência: um velho-novo desafio para a atenção à saúde. Rev Bras Educ Med. 2005; 29(1):55-63.

2. Comitê do PHTLS da National Association of Emergency Medical Technicians (NAEMT) em colaboração com o Comitê de Trauma do Colégio Americano de Cirurgiões. Atendimento pré-hospitalar ao traumatizado: básico e avançado. Rio de Janeiro: Elsevier; 2004. p.10-29. [Tradução do original: PHTL basic and advanced prehospital trauma life support].

3. Brasil. Ministério da Saúde. Biblioteca Virtual em Saúde. Acidente e violências: conceito [Internet]. Brasília (DF): Ministério da Saúde; 2008. [citado 2008 Abr 6]; Disponível em: http://bvsms2.saude.gov.br/php/level.php?lang= pt\&component $=51 \&$ item $=40$

4. Dahlberg LL, Krug EG. Violência: um problema global de saúde pública. Cienc Saude Coletiva. 2006; 11(Supl): 116378.

5. Souza ER, Lima MLC. Panorama da violência urbana no Brasil e suas capitais. Cienc Saude Coletiva. 2006; 11(Supl): 1211-22.

6. Minayo MCS. A inclusão da violência na agenda da saúde: trajetória histórica. Cienc Saude Coletiva. 2006; 11(Supl): 1259-67.

7. Schraiber LB, D’Oliveira AFPL, Couto MT. Violência e saúde: estudos científicos recentes. Rev Saude Publica $=\mathrm{J}$ Public Health. 2006; 40(N Esp): 112-20.

8. Pereira WAP, Lima MADS. Atendimento pré-hospitalar: caracterização das ocorrências de acidente de trânsito. Acta Paul Enferm. 2006; 19(3): 279-83.

9. Deslandes SF, Souza ER, Minayo MCS, Costa CRBSF, Krempel M, Cavalcanti ML, et al . Diagnostic characterization of services providing care to victims of accidents and violence in five Brazilian state capitals. Cienc Saude Coletiva. 2006; 11(2):385-96.

10. Leal LN. Expectativa de vida: 71,3 anos. JC e-mail 2659, de atruly integrated healthcare system (basic network, secondary and tertiary sectors) and team qualification, through efficient public policies, so that morbidity and mortality can be reduced in this particular population. It is possible to act in the face of this phenomenon according to a logic of prevention, promotion and valuation of $\operatorname{life}^{(31)}$.

Both healthcare managers and healthcare teams that work in these units need to assume organizational issues at the emergency units and their ethical implications because, even though intra-hospital healthcare conditions are still not in accordance with public policies, the professionals need to deliver care to trauma victims, aiming at beneficence and reduction of the risk of harm associated with this type of healthcare.

Although this discussion is still limited, there is always the possibility of studying other aspects more in-depth, involving organization, ethics and care at the emergency services, which will contribute to narrow the gaps between the low level of scientific production in Brazil, compared with the huge importance this epidemiological problem represents for the population, not only in social and economic terms, but also with respect to human life.

02 de Dezembro de 2004. [nternet]. SBPC; c2002. [citado 2008 Jul 14 [ cerca de 2 p.]. Disponível em: http:// www.jornaldaciencia.org.br/Detalhe.jsp?id $=23648$

11. Deslandes SF. $\mathrm{O}$ atendimento às vítimas de violência na emergência: prevençäo numa hora dessas? Cienc Saude Coletiva. 1999; 4(1): 81-94.

12. Leal SMC, Lopes MJM. A violência como objeto da assistência em um hospital de trauma: o olhar da enfermagem. Cienc Saude Coletiva. 2005; 10(2):419-31.

13. Brasil. Conselho Federal de Medicina. Resolução CFM n ${ }^{\circ}$ 1451/95, de 10 março 1995 [Internet]. São Paulo: CFM; c2003-2006. [citado 2006 Jan 31]. Disponível em: http:// www.cremesp.org.br/administra/deptos/def/doc/ RESOLUCAO_CFM_145195.doc

14. Rother ET. Revisão sistemática X revisão narrativa [editorial]. Acta Paul Enferm. 2007; 20(2):v-vi.

15. Campos GWS. Considerações sobre a arte e a ciência da mudança: revolução das coisas e reforma das pessoas. $\mathrm{O}$ caos da saúde. In: Cecilio LCO, organizador. Inventando a mudança na saúde. 3a ed. São Paulo: Hucitec; 2006. p. 2987.

16. Lunardi Filho WD. O mito da subalternidade do trabalho da enfermagem à medicina. Pelotas: Ed. Universitária UFPel; 2004.

17. Marques GQ, Leal SMC, Lima MADS, Bonilha ALL, Lopes MJM. As práticas e o cotidiano de profissionais em serviços públicos de saúde, na ótica de estudos acadêmicos. Online Braz J Nurs (Online). 2007; 6(2): 1-5.

18. Bittencourt RJ, Hortale VA. A qualidade nos serviços de emergência de hospitais públicos e algumas considerações sobre a conjuntura recente no município do Rio de Janeiro. Cienc Saude Coletiva. 2007; 12(4): 929-34.

19. Cecilio LCO, organizador. Inventando a mudança na saúde. 3a ed. São Paulo: Hucitec; 2006.

20. Cohen C, Segre M. Breve discurso sobre valores, moral, 
eticidade e ética. In: Segre M, Cohen C, organizadores. Bioética. 2a ed. ampl. São Paulo: EDUSP; 1999. p. 13-22.

21. Beauchamp TL, Childress JF. Princípios de ética biomédica. São Paulo: Loyola; 2002.

22. Gianberardino Filho D. Bioética em emergências pediátricas. In: Urban CA, editor. Bioética clínica. Rio de Janeiro: Revinter; 2003. p. 384-9.

23. Dias-da-Costa JS, Olinto MTA, Gigante DP, Menezes AMB, Macedo S, Daltoé T, et al. Utilização de serviços ambulatoriais de saúde em Pelotas, Rio Grande do Sul, Brasil: alguns fatores relacionados com as consultas médicas acima da média. Cad Saude Publica $=$ Rep Public Health. 2008; 24(2): 353-63.

24. Santos JS, Scarpelini S, Brasileiro SLL, Ferraz CA, Dallora MELV, Sá MFS. Avaliação do modelo de organização da Unidade de Emergência do HCFMRP-USP, adotando, como referência, as políticas nacionais de atenção às urgências e de humanização. Medicina (Ribeirão Preto). 2003; 36(2/4):498-515.

25. Costa ALRC. As múltiplas formas de violência no trabalho de enfermagem: o cotidiano de trabalho no setor de emergência e urgência clínica em um hospital público [tese]. Ribeirão Preto: Escola de Enfermagem de Ribeirão Preto da Universidade de São Paulo; 2005.

26. Belancieri MF, Bianco MHBC. Estresse e repercussões psicossomáticas em trabalhadores da área da enfermagem de um hospital universitário. Texto \& Contexto Enferm. 2004; 13(1):124-31.

27. Coutrin RMGS, Freua PR, Guimarães CM. Estresse em enfermagem: uma análise do conhecimento produzido na literatura brasileira no período de 1982 a 2001. Texto \& Contexto Enferm. 2003; 12(4):486-94.

28. Ghiorzi AR. O quotidiano dos trabalhadores em saúde. Texto \& Contexto Enferm. 2003; 12(4):551-8.

29. Brasil. Ministério da Saúde. Secretaria de Atenção à Saúde. Política nacional de atenção às urgências. Brasília: Editora MS; 2004.

30. Pereira WR, Bellato R. A relação entre a precarização do ambiente físico e o risco de infecção hospitalar: um olhar sob a perspectiva da ética, dos direitos e da cidadania. Texto \& Contexto Enferm. 2004; 13(N Esp):17-24.

31. Gonçalves L, Magalhães ZR. Acompanhamento do trabalhador de enfermagem em reabilitação: a experiência de um hospital universitário. Texto \& Contexto Enferm. 2003; 12(4):519-27. 